\title{
The microstructure and creep properties of as-cast Mg-Sn-Si-(Al) magnesium alloys
}

\author{
Tomasz Rzychoń ${ }^{1}$ (1)
}

Received: 25 January 2020 / Revised: 21 July 2020 / Accepted: 30 July 2020 / Published online: 8 August 2020

(c) The Author(s) 2020

\begin{abstract}
Magnesium alloys containing rare earth metals exhibit good creep resistance up to $300{ }^{\circ} \mathrm{C}$ and good tensile properties at ambient temperature. The high cost of rare earth has led to studies regarding the creep resistance of $\mathrm{Mg}$ alloys with cheap alloying elements ( $\mathrm{Sn}, \mathrm{Ca}, \mathrm{Si}$ ) that could be substituted for $\mathrm{Mg}$ - $\mathrm{RE}$ alloys. In this paper, the influence of $\mathrm{Si}$ and $\mathrm{Al}$ on microstructure and mechanical properties of Mg-7Sn alloy was investigated using optical (LM), scanning electron microscopy (SEM), transmission electron microscopy (TEM), X-ray diffraction analysis (XRD), tensile tests and creep tests at 200-250 ${ }^{\circ} \mathrm{C}$. Microstructure of as-cast alloys consists of $\alpha-\mathrm{Mg}$ matrix and intermetallic compounds at the interdendritic regions. Heat treatment consisting of solid solution treatment and ageing increases the tensile properties at ambient temperature due to the precipitation of the fine $\mathrm{Mg}_{2} \mathrm{Sn}$ phase. The creep resistance of aged $\mathrm{Mg}-7 \mathrm{Sn}$ alloy is poor. The addition of $\mathrm{Si}$ and $\mathrm{Al}$ to $\mathrm{Mg}$ $7 \mathrm{Sn}$ alloy has resulted in improving the creep resistance due to the refinement of $\mathrm{Mg}_{2} \mathrm{Sn}$ phase and the appearance of $\mathrm{Mg}_{2} \mathrm{Si}$ phase at the grain boundaries. The $\mathrm{Mg}-7 \mathrm{Sn}-1 \mathrm{Si}$ alloy exhibits better creep resistance at $200{ }^{\circ} \mathrm{C}$ than $\mathrm{Mg}-7 \mathrm{Sn}-5 \mathrm{Si}$ and $\mathrm{Mg}-7 \mathrm{Sn}$ $5 \mathrm{Si}-2 \mathrm{Al}$ alloys. The $\mathrm{Mg}-7 \mathrm{Sn}$ alloys with $5 \% \mathrm{Si}$ have better creep properties at $250{ }^{\circ} \mathrm{C}$ in comparison to $\mathrm{Mg}$ - $7 \mathrm{Sn}-1 \mathrm{Si}$ alloy.
\end{abstract}

Keywords Magnesium alloys $\cdot$ Mg-sn alloys $\cdot$ Mg-si alloys $\cdot$ Microstructure $\cdot$ Creep properties

\section{Introduction}

Magnesium alloys due to their low density are attractive materials for the aerospace and automotive industries [1]. Commercial $\mathrm{Mg}-\mathrm{Al}$ alloys are characterized by low operating temperature (up to about $120^{\circ} \mathrm{C}$ ), thus intensive research is being carried out to improve the creep resistance of magnesium alloys. Increase in creep resistance of $\mathrm{Mg}-\mathrm{Al}$ alloys is achieved by introducing alloying elements such as silicon $[2,3]$, strontium [4], calcium [3, 5] and rare earth metals [6]. These alloys can be operated up to a temperature of about $200{ }^{\circ} \mathrm{C}$. In the last two decades, the Al-free magnesium alloys with rare earth metals, yttrium, strontium and manganese (Mg-Zn-RE, Mg-Y-Nd-Zr, Mg-Sr-Mn, and Mg-Nd-Gd$\mathrm{Zr}$ ) have been developed, which can be used for structural elements operating up to a temperature of $250{ }^{\circ} \mathrm{C}$ (even up to $300^{\circ} \mathrm{C}$ during short-term operation) [7-9]. In the case of $\mathrm{Al}$-free magnesium alloys good creep properties are related

Tomasz Rzychoń

tomasz.rzychon@polsl.pl

1 Faculty of Materials Science, Silesian University of Technology, Katowice, Poland to the presence of the strengthening phases characterized by good thermal stability at elevated temperatures. However, these alloys are expensive due to the high cost of rare earth metals and also in some cases technological problems in casting. Thus, there is a need for an alternative alloy which has similar properties to $\mathrm{Mg}-\mathrm{Y}-\mathrm{Nd}-\mathrm{Zr}$ and $\mathrm{Mg}-\mathrm{Nd}-\mathrm{Gd}-\mathrm{Zr}$ alloys, but which are characterized by good casting properties and lower manufacturing costs compared to magnesium alloys consisting of rare-earth metals [10].

Silicon-that forms the $\mathrm{Mg}_{2} \mathrm{Si}$ phase in magnesium alloys-is one of the alloying elements that can favorably affect the creep resistance of magnesium alloys at low manufacturing costs. The $\mathrm{Mg}_{2} \mathrm{Si}$ phase exhibits a high melting temperature $\left(1085^{\circ} \mathrm{C}\right)$, high hardness, high elastic modulus and low thermal coefficient [11]. If the Si content in the magnesium alloys is below $1.34 \mathrm{wt} \%$, the $\mathrm{Mg}_{2} \mathrm{Si}$ phase is formed as a result of the eutectic reaction, while above 1.34 $\mathrm{wt} \%, \mathrm{Mg}_{2} \mathrm{Si}$ primary crystals are also formed. Obviously, the presence of primary $\mathrm{Mg}_{2} \mathrm{Si}$ compound which forms the large particles in the $\alpha-\mathrm{Mg}$ matrix adversely affects mechanical properties [12]. Research to modify the shape and size of primary crystals has not contributed to significant improvements in mechanical properties of $\mathrm{Mg}$-Si alloys containing 
more than $1.34 \mathrm{wt} \% \mathrm{Si}$ [11]. To increase mechanical properties at ambient and elevated temperatures of Si-rich $\mathrm{Mg}$ alloys, alloying elements which will promote the formation of fine precipitates strengthening of the matrix can be added. One of these elements is tin, which is readily available and forms the $\mathrm{Mg}_{2} \mathrm{Sn}$ intermetallic compound with a high melting temperature of about $770{ }^{\circ} \mathrm{C}$. The solubility of $\mathrm{Sn}$ in $\alpha-\mathrm{Mg}$ provides a fundamental basis for improving the mechanical properties of these alloys through ageing and has a positive effect on the mechanical properties at ambient and elevated temperatures [13, 14].

The present paper is aimed to develop as-cast $\mathrm{Mg}-\mathrm{Sn}$ alloys with the addition of high content $\mathrm{Si}$ and investigates their microstructure, mechanical properties at ambient temperature and creep properties.

\section{Experimental method}

Magnesium alloys containing silicon, tin and aluminum were prepared, and its composition was analyzed by X-ray fluorescence spectroscopy (Table 1). Commercially pure $\mathrm{Mg}$ (99.8\%), Si (99.5\%), Sn (99.4\%) and $\mathrm{Al}(99.6 \%)$ were used. Melting of the alloys was performed by induction melting in an alumina crucible under the protection of an argon atmosphere. The melt was maintained at $800{ }^{\circ} \mathrm{C}$ for $3 \mathrm{~min}$ then poured into sand moulds. T6 heat treatment (solution treatment + artificial ageing) was carried out to enhance the mechanical properties. The solution treatment was performed at $500{ }^{\circ} \mathrm{C}$ for $24 \mathrm{~h}$ in an argon atmosphere and water quenched to room temperature. The ageing treatment was performed at temperatures in the range between $200{ }^{\circ} \mathrm{C}$ and $250{ }^{\circ} \mathrm{C}$ from 4 to $148 \mathrm{~h}$.

The microstructure of the alloys was analyzed by light microscopy (LM) and scanning electron microscopy (SEM) using a FE SEM Hitachi S-3400 N scanning electron microscope. Observations were used at SE (secondary electron) and BSE (back-scaterred electron) modes. Energy-dispersive $\mathrm{X}$-ray spectroscopy (EDS) analysis was performed at the acceleration voltage of $15 \mathrm{keV}$. Microstructure observations were performed on the samples etched in reagent containing $3 \mathrm{~mL} \mathrm{HNO}_{3}$ and $97 \mathrm{~mL} \mathrm{C}_{2} \mathrm{H}_{5} \mathrm{OH}$. The FEI Titan 83/300 transmission electron microscope (TEM) was also used to

Table 1 Chemical composition of the tested alloy (wt $\%$ )

\begin{tabular}{llllll}
\hline Alloy & \multicolumn{6}{l}{ Chemical composition, wt\% } \\
\cline { 2 - 6 } & $\mathrm{Mg}$ & $\mathrm{Si}$ & $\mathrm{Sn}$ & $\mathrm{Al}$ & Others (Fe, Ni) \\
\hline Mg-7Sn & Balance & 0.1 & 7.0 & - & $<0.02$ \\
Mg-7Sn-1Si & Balance & 0.8 & 7.1 & - & $<0.02$ \\
Mg-7Sn-5Si & Balance & 5.2 & 7.4 & - & $<0.02$ \\
Mg-7Sn-5Si-2Al & Balance & 5.2 & 7.1 & 1.8 & $<0.02$ \\
\hline
\end{tabular}

analyze the phase composition and chemical composition of the intermetallic phases. Thin foils were prepared by electrolytic polishing. The electrolyte composition was $5.3 \mathrm{~g}$ lithium chloride, $11.16 \mathrm{~g}$ magnesium perchlorate, $500 \mathrm{~mL}$ methanol, and $100 \mathrm{~mL}$ 2-butoxyethanol. Polishing was performed at $-45{ }^{\circ} \mathrm{C}$ and $20 \mathrm{~V}$. X-ray diffraction patterns (XRD) were obtained with a JEOL JDX-7S diffractometer with a copper anode. Registration was performed by $0.02^{\circ}$ stepwise regression for $2 \theta$ ranging from $10^{\circ}$ to $90^{\circ} 2 \theta$. Phase identification was performed using the ICDD PDF- $4+$ database. Hardness measurement was carried out on Vickers hardness tester (Duramin A5) at a load of $2 \mathrm{~kg}$ according to ASTM E92-17 standard (ASTM E92-17. Standard Test Methods for Vickers Hardness and Knoop Hardness of Metallic Materials). Standard creep test specimens machined out from the castings in accordance with ASTM E139-11(2018) standard, were subjected to a constant load creep test at $200-250{ }^{\circ} \mathrm{C}$ at stresses of 15-60 MPa using the Zwick Kappa 50DS creeptesting machine. Creep strain was measured by extensometers which were attached directly to the gauge section of specimens. The length of the specimen was $100 \mathrm{~mm}$, the gage length was $60 \mathrm{~mm}$ and the diameter of the reduced section was $6 \mathrm{~mm}$.

\section{Results and discussion}

\subsection{Microstructure of Mg-Si-Sn alloys}

Microstructure of sand-cast Mg-7Sn, Mg-7Sn-1Si, Mg-7Sn5Si and Mg-7Sn-5Si-2Al alloys is shown in Figs. 1 and 2. Details of the phase composition identification were presented in a previous paper [15]. The microstructure of sand-cast Mg-7Sn alloy (Figs. 1a, 2a) is composed of $\alpha-\mathrm{Mg}$ magnesium matrix and eutectic $\mathrm{Mg}_{2} \mathrm{Sn}$ phase at the grain boundaries. The clear segregation of tin inside the dendrites of the $\alpha-\mathrm{Mg}$ is also observed (in the dark areas visible in the LM image-Fig. 1a, increased tin content was found). The addition of $1 \mathrm{wt} \%$ Si to Mg-7Sn alloy (Fig. 1a, b) caused the formation of the $\mathrm{Mg}_{2} \mathrm{Si}$ phase in the form of Chinese script. The minor amounts of $\mathrm{Sn}$ are dissolved in the $\mathrm{Mg}_{2} \mathrm{Si}$ phase and the minor amounts of $\mathrm{Si}$ are dissolved in the $\mathrm{Mg}_{2} \mathrm{Sn}$ phase [15]. When the Si content is increased from 1 to 5\%, substantial changes have occurred in the microstructure. In the Mg-7Sn-5Si alloy (Fig. 2c) the $\alpha-\mathrm{Mg}$ matrix, eutectic $\mathrm{Mg}_{2} \mathrm{Sn}$ phase, the Chinese script type $\mathrm{Mg}_{2} \mathrm{Si}$ phase and additionally coarse primary crystals of $\mathrm{Mg}_{2} \mathrm{Si}$ compound are observed. The phase composition of Mg-7-Sn-5Si alloy did not change when $2 \% \mathrm{Al}$ was added to alloy, because $\mathrm{Al}$ dissolves in the $\alpha-\mathrm{Mg}$ solid solution. In the all tested alloys, the significant solute segregation in $\alpha-\mathrm{Mg}$ solid solution was found. The tin content increases towards the interdendritic regions as a results of coring during solidification (LM 

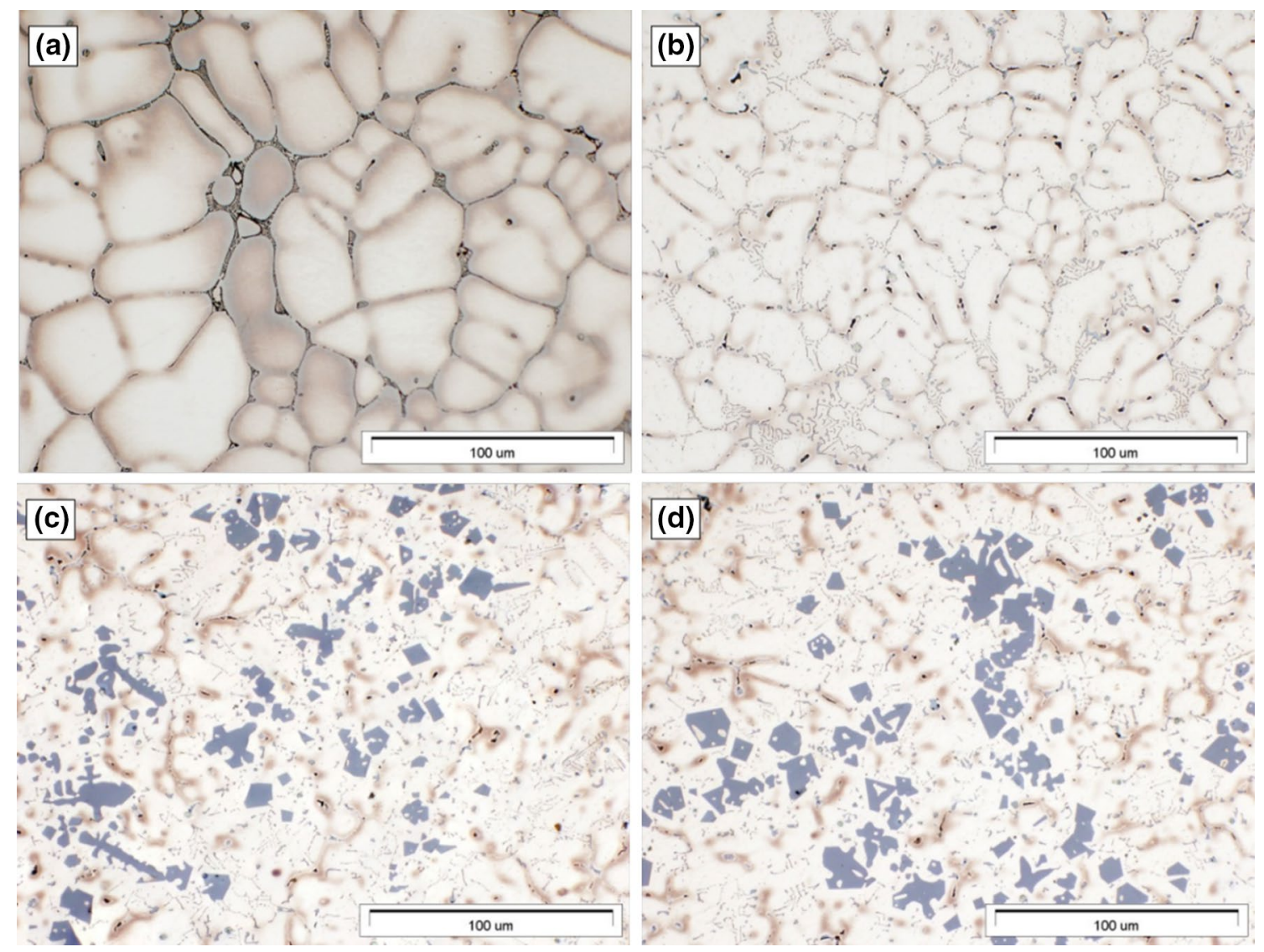

Fig. 1 Microstructure of sand-cast Mg-7Sn (a), Mg-7Sn-1Si (b), Mg-7Sn-5Si (c), Mg-7Sn-5Si-2Al (d) alloys

images show the existence of diffusive dark areas and BSE images show the presence of diffusive bright areas at the dendritic and grain boundaries).

The solution heat-treatment of tested alloys at $500{ }^{\circ} \mathrm{C}$ for $24 \mathrm{~h}$ leads to the dissolution the eutectic $\mathrm{Mg}_{2} \mathrm{Sn}$ phase in the $\alpha-\mathrm{Mg}$ solid solution and homogenization of chemical composition in the $\alpha-\mathrm{Mg}$ matrix. It is obviously related to the high solubility of $\mathrm{Sn}$ in the $\mathrm{Mg}$ at $500{ }^{\circ} \mathrm{C}$. The $\mathrm{Mg}_{2} \mathrm{Si}$ phase, which is formed as a result of the eutectic reaction and is characterized by a Chinese script morphology, undergoes spheroidization during solution heat treatment (Fig. 3a, b). Due to the very low solubility of $\mathrm{Si}$ in $\mathrm{Mg}$, it can be expected that the diffusion of $\mathrm{Si}$ atoms runs along with the $\mathrm{Mg} / \mathrm{Mg}_{2} \mathrm{Si}$ interface during spheroidization process. The diffusion of $\mathrm{Si}$ inside the $\mathrm{Mg}_{2} \mathrm{Si}$ particles is rather unlikely because the $\mathrm{Mg}_{2} \mathrm{Si}$ phase exists only at stoichiometric composition [16]. The $\mathrm{Mg}_{2} \mathrm{Si}$ primary crystals exhibit a high stability of shape and chemical composition during the solution heat-treatment at a temperature of $500{ }^{\circ} \mathrm{C}$ for $24 \mathrm{~h}$.

During the aging of the tested alloys at $250{ }^{\circ} \mathrm{C}$, the fine precipitates of $\mathrm{Mg}_{2} \mathrm{Sn}$ phase are formed regardless of the silicon content in the alloy (Fig. 4). The morphology of the $\mathrm{Mg}_{2} \mathrm{Si}$ primary crystals and globular $\mathrm{Mg}_{2} \mathrm{Si}$ compound remained unchanged after aging. $\mathrm{Al}$ in $\mathrm{Mg}-7 \mathrm{Sn}-5 \mathrm{Si}-2 \mathrm{Al}$ alloy does not form any phases during aging and is completely dissolved in the $\alpha-\mathrm{Mg}$ solid solution. The equilibrium $\mathrm{Mg}_{2} \mathrm{Sn}$ phase is formed in the early stages of ageing and it is not preceded by the precipitation of other non-equlibrium phases. Obviously, with extending ageing time, coarsening and increase of the $\mathrm{Mg}_{2} \mathrm{Sn}$ phase content were found. The precipitation process of the $\mathrm{Mg}_{2} \mathrm{Sn}$ phase in the $\mathrm{Mg}-\mathrm{Sn}$-(X) alloys has been widely reported [17-26]. According to previous studies, it was found that lath-shaped, plate-like and polygon $\mathrm{Mg}_{2} \mathrm{Sn}$ precipitates may be formed after ageing in these alloys. Similar results were obtained in case of alloys being the subject of this paper. The lath-shaped precipitates of $\mathrm{Mg}_{2} \mathrm{Sn}$ phase dominate inside the $\alpha-\mathrm{Mg}$ grains. They are mainly formed on basal planes of the $\alpha-\mathrm{Mg}$ matrix (Fig. 5, type 1) and exhibit the orientation relationship: $(0001)_{\alpha-\mathrm{Mg}} / /$ $(110)_{\mathrm{Mg} 2 \mathrm{Sn}},[11-20]_{\alpha-\mathrm{Mg}} /\left[[001]_{\mathrm{Mg} 2 \mathrm{Sn}}\right.$. For the polygonal precipitates (Fig. 5, type 2) growing in the perpendicular direction to (0001) $)_{\alpha-\mathrm{Mg}}$ the orientation relationship can be described to be $(2-1-10)_{\alpha-\mathrm{Mg}} / /(-110)_{\mathrm{Mg} 2 \mathrm{Sn}},[0001]_{\alpha-\mathrm{Mg}} / /$ $[111]_{\mathrm{Mg} 2 \mathrm{Sn}}$. The plate-like precipitates (Fig. 5, type 3) with a hexagonal shape when the electron beam direction is parallel to [0001] $\alpha-\mathrm{Mg}$ are also formed during ageing of the 

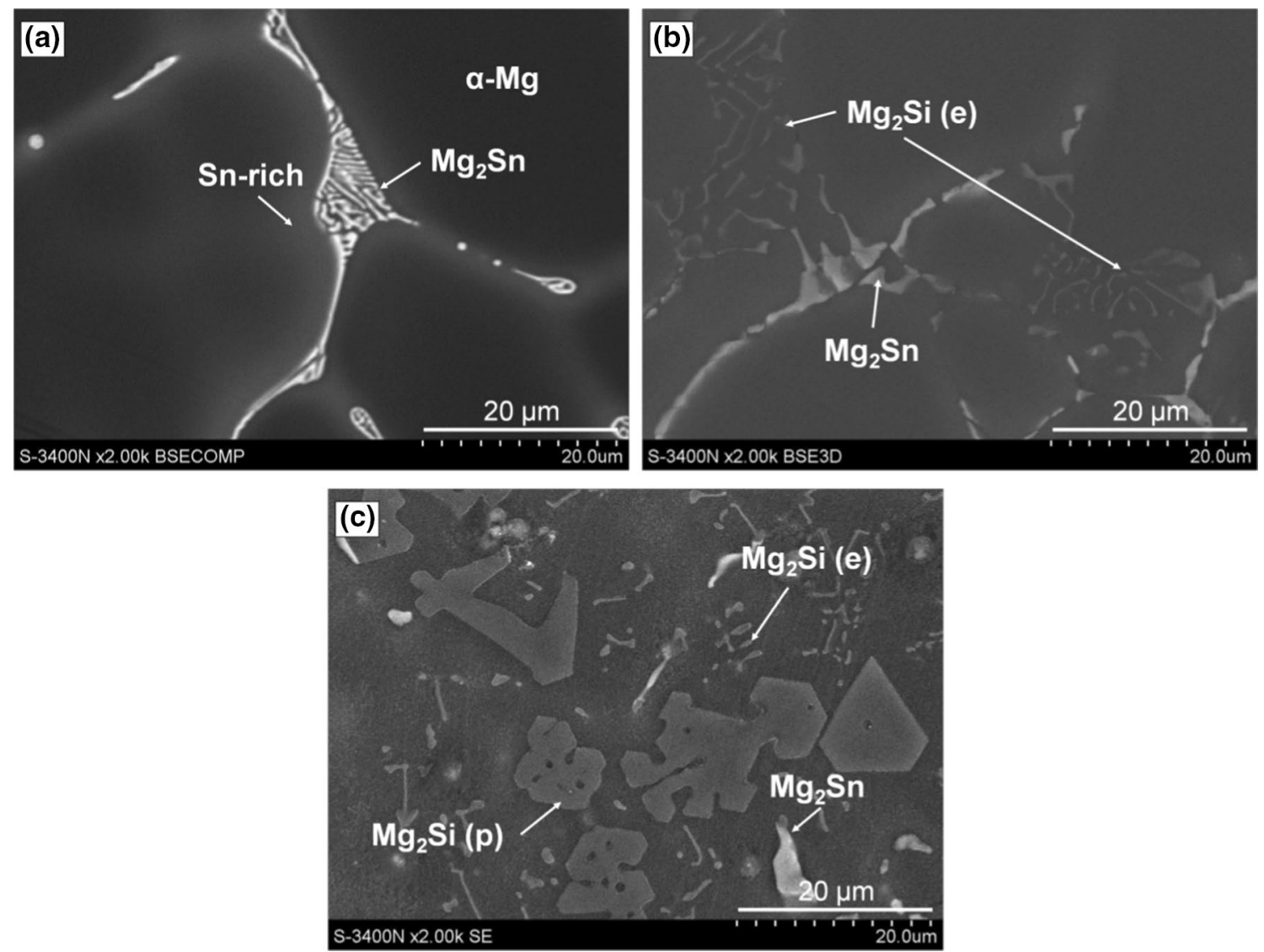

Fig. 2 SEM images of sand-cast Mg-7Sn alloy (a), sand-cast Mg-7Sn-1Si alloy (b), sand-cast Mg-7Sn-5Si alloy (c)
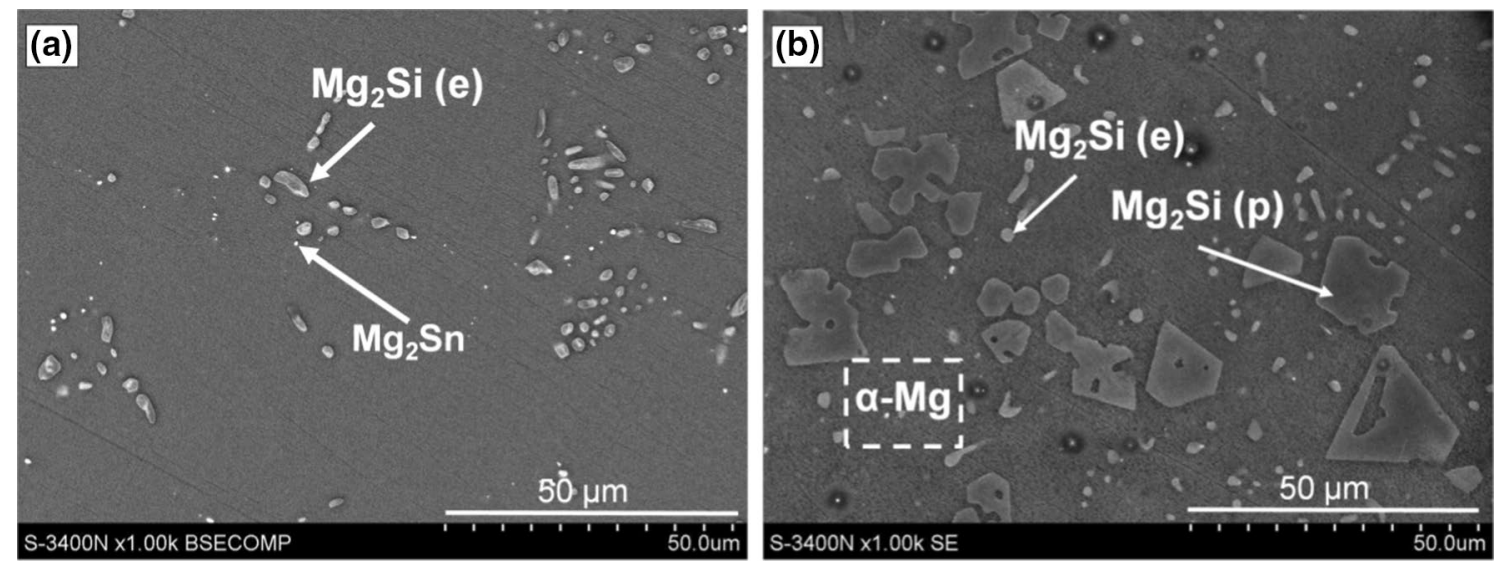

Fig. 3 SEM images of solution-treated $\left(500{ }^{\circ} \mathrm{C} / 24 \mathrm{~h} /\right.$ water) $\mathrm{Mg}-7 \mathrm{Sn}-1 \mathrm{Si}$ alloy (a) and Mg-7Sn-5Si alloy (b)

tested alloys. Their orientation relationship was reported in [22] and described approximately as $(0001)_{\alpha-\mathrm{Mg}} / /(111)_{\mathrm{Mg} 2 \mathrm{Sn}}$, $[2-1-10]_{\alpha-\mathrm{Mg}}$ deviates by about $9^{\circ}$ from $[-110]_{\mathrm{Mg} 2 \mathrm{Sn}}$.

In the tested alloys the length of the lath-shaped precipitates decreases when $\mathrm{Al}$ and $\mathrm{Si}$ are added to the $\mathrm{Mg}-\mathrm{Sn}$ alloys (Table 2). The addition of Al significantly decreases the size of lath-shaped $\mathrm{Mg}_{2} \mathrm{Sn}$ precipitates in $\mathrm{Mg}-7 \mathrm{Sn}-5 \mathrm{Si}$ alloy. However, increasing the Si content from 1 to $5 \%$ does not cause significant refinement of the $\mathrm{Mg}_{2} \mathrm{Sn}$ precipitates.

It was reported that the effect of microalloying additions on the refinement of $\mathrm{Mg}_{2} \mathrm{Sn}$ precipitates is related to the formation of clusters or minor precipitates in the $\alpha-\mathrm{Mg}$ 

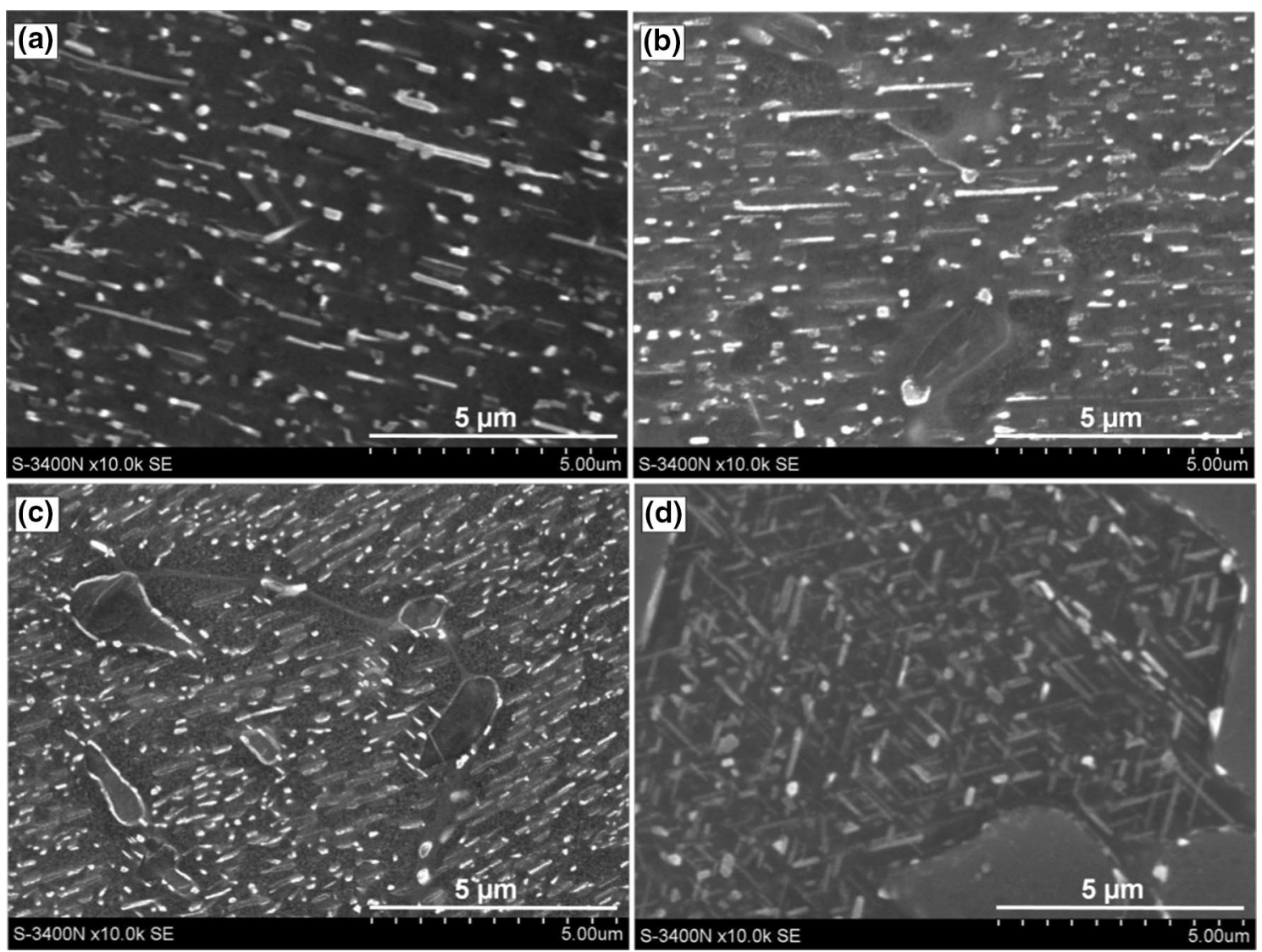

Fig. 4 SEM images of peak aged alloys with the microstructure consisting of fine precipitates of $\mathrm{Mg}_{2} \mathrm{Sn}$ phase. $\mathrm{Mg}$-7Sn alloy aged at $250{ }^{\circ} \mathrm{C} / 48 \mathrm{~h}(\mathbf{a}), \mathrm{Mg}-7 \mathrm{Sn}-1 \mathrm{Si}$ alloy aged at $250{ }^{\circ} \mathrm{C} / 72 \mathrm{~h}(\mathbf{b}), \mathrm{Mg}-7 \mathrm{Sn}-5 \mathrm{Si}$ alloy aged at $250{ }^{\circ} \mathrm{C} / 72 \mathrm{~h}(\mathbf{c}), \mathrm{Mg}-7 \mathrm{Sn}-5 \mathrm{Si}-2 \mathrm{Al}$ aged at $250{ }^{\circ} \mathrm{C} / 20 \mathrm{~h}(\mathbf{d})$

matrix, which may be effective catalysts for nucleation of the strengthening precipitates in the $\mathrm{Mg}-\mathrm{Sn}$ system [14]. Silicon in the tested alloys forms the $\mathrm{Mg}_{2} \mathrm{Si}$ phase and its solubility in the $\alpha-\mathrm{Mg}$ solid solution is very low (0.005 at.\%) and probably $\mathrm{Si}$ is not able to create nano-clusters reducing the size of $\mathrm{Mg}_{2} \mathrm{Sn}$ precipitates. Microscopic observations did not allow to determine whether silicon can form nanoclusters or nanoparticles in the $\alpha-\mathrm{Mg}$ matrix, but it can be seen that $\mathrm{Si}$ is dissolved in the $\mathrm{Mg}_{2} \mathrm{Sn}$ precipitates (Fig. 6). The incorporation of the $\mathrm{Si}$ atoms in the crystal structure of $\mathrm{Mg}_{2} \mathrm{Sn}$ phase may hinder its growth during ageing, thus $\mathrm{Si}$ may have a contribution to the refinement of $\mathrm{Mg}_{2} \mathrm{Sn}$ precipitates regardless of Si content in alloys. The $\mathrm{Al}$ dissolved in the $\alpha-\mathrm{Mg}$ can also affect the growth rate and a number of nuclei of the $\mathrm{Mg}_{2} \mathrm{Sn}$ precipitates during aging by reducing the solubility of $\mathrm{Sn}$ in $\alpha-\mathrm{Mg}$ or change the interfacial energy between $\mathrm{Sn}$ and $\alpha-\mathrm{Mg}$ solid solution [23]. Thus the driving force for the nucleation of $\mathrm{Mg}_{2} \mathrm{Sn}$ precipitates will be increased and the greater the number of precipitates per unit volume can be formed. Microscopic observations (Fig. 6) also revealed that nano-clusters of $\mathrm{Al}$ may be formed at the surface of $\mathrm{Mg}_{2} \mathrm{Sn}$ particles and these nano-clusters may have acted as heterogeneous nucleation sites of these precipitates.
Figure 7 shows the microstructure of the peak-aged $\left(250{ }^{\circ} \mathrm{C}\right.$ ) alloys with the revealed the $\alpha-\mathrm{Mg}$ grains and Table 2 presents the results of the grain size measurements. It can be seen that the $\mathrm{Mg}$-Sn alloys consisting of $\mathrm{Si}$ exhibit lower $\alpha-\mathrm{Mg}$ grain size in comparison to $\mathrm{Mg}$-Sn alloy due to the existence of the $\mathrm{Mg}_{2} \mathrm{Si}$ compound in the interdendritic regions, which hinders grain growth after casting process as well as during the solution heat treatment at $500{ }^{\circ} \mathrm{C}$.

\subsection{Mechanical properties}

The sand-cast Mg-7Sn alloy exhibits low hardness $(\sim 45$ $\mathrm{HV})$. The addition of $1 \mathrm{wt} \% \mathrm{Si}$ increases the hardness of $\mathrm{Mg}$-Sn alloy to $51 \mathrm{HV}$ due to the formation of the eutectic $\mathrm{Mg}_{2} \mathrm{Si}$ phase. When the Si content increased to $5 \%$, an increase in hardness of up to $63 \mathrm{HV}$ was noted due to the appearance of primary crystals of $\mathrm{Mg}_{2} \mathrm{Si}$ compound in the microstructure. The addition of $2 \mathrm{wt} \% \mathrm{Al}$ also caused a significant increase in hardness (71 HV). The content of $\mathrm{Mg}_{2} \mathrm{Si}$ and $\mathrm{Mg}_{2} \mathrm{Sn}$ compounds in $\mathrm{Mg}-7 \mathrm{Sn}-5 \mathrm{Si}$ and $\mathrm{Mg}-7 \mathrm{Sn}-5 \mathrm{Si}-$ $2 \mathrm{Al}$ alloys is comparable, therefore the higher hardness of $\mathrm{Mg}-7 \mathrm{Sn}-5 \mathrm{Si}-2 \mathrm{Al}$ is attributed to the presence of $\mathrm{Al}$ solute atoms in $\alpha-\mathrm{Mg}$ solid solution and smaller $\alpha-\mathrm{Mg}$ grain size. 

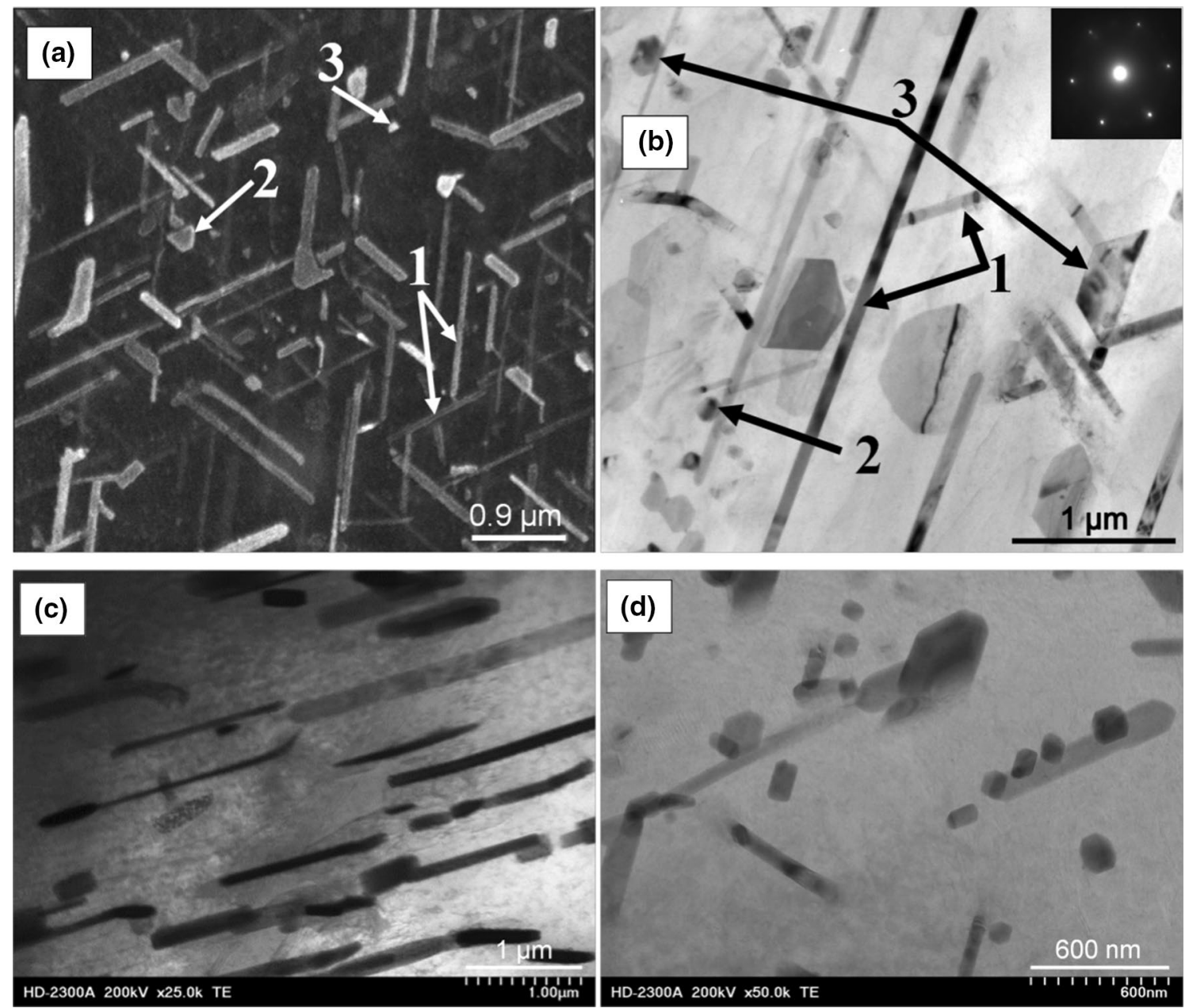

Fig. 5 The lath-shaped (1), polygonal (2) and plate-shaped (3) of $\mathrm{Mg}_{2} \mathrm{Sn}$ precipitates observed in the $\mathrm{Mg}-7 \mathrm{Sn}-5 \mathrm{Si}-2 \mathrm{Al}$ alloy aged at $250{ }^{\circ} \mathrm{C}$ for $20 \mathrm{~h}$ (a), TEM micrograph of $\mathrm{Mg}-7 \mathrm{Sn}-5 \mathrm{Si}-2 \mathrm{Al}$ alloy aged at $250{ }^{\circ} \mathrm{C}$ for $20 \mathrm{~h}$, which were obtained in the $[0001]_{\mathrm{Mg}}$ beam direc- tion (b), STEM micrograph of Mg-7Sn-1Si alloy aged at $250{ }^{\circ} \mathrm{C} / 72 \mathrm{~h}$ registered in the $[2-1-10]_{\mathrm{Mg}}$ beam direction (c), STEM image of precipitates of $\mathrm{Mg}_{2} \mathrm{Sn}$ phase in $\mathrm{Mg}-7 \mathrm{Sn}-5 \mathrm{Si}-2 \mathrm{Al}$ alloy aged at $250{ }^{\circ} \mathrm{C}$ for $20 \mathrm{~h}(\mathbf{d})$

Table 2 The results of hardness measurements, length measurements of $\mathrm{Mg}_{2} \mathrm{Sn}$ phase and $\alpha-\mathrm{Mg}$ grain size in tested peak-aged alloys

\begin{tabular}{lllllll}
\hline Alloy & $\begin{array}{l}\text { Hardness of solution } \\
\text { treated, HV }\end{array}$ & $\begin{array}{l}\text { Time to peak } \\
\text { hardness, } h\end{array}$ & $\begin{array}{l}\text { Max. hard- } \\
\text { ness, HV }\end{array}$ & $\begin{array}{l}\text { Hardness } \\
\text { increment }\end{array}$ & $\begin{array}{l}\text { Length of Mg } \mathrm{Mn}_{2} \mathrm{Sn} \\
\text { precipitates, } \mu \mathrm{m}\end{array}$ \\
\hline Mg-7Sn & 40 & 48 & 51 & 11 & $1.57(1.3)$ & $350(145)$ \\
Mg-7Sn-1Si & 43 & 72 & 58 & 15 & $1.14(0.8)$ & $285(155)$ \\
Mg-7Sn-5Si & 60 & 72 & 76 & 16 & $1.02(0.31)$ & $211(115)$ \\
Mg-7Sn-5Si-2Al & 65 & 20 & 84 & 19 & $0.87(0.70)$ & $192(67)$ \\
\hline
\end{tabular}

In brackets the standard deviation is given

The solution heat treatment at $500{ }^{\circ} \mathrm{C}$ reduced hardness of the tested alloys (Mg-7Sn alloy-40 HV, Mg-7Sn-1Si alloy-43 HV, Mg-7Sn-5Si alloy-60 HV, Mg-7Sn-5Si alloy- $65 \mathrm{HV}$ ) as a result of the dissolution of $\mathrm{Mg}_{2} \mathrm{Sn}$ phase in the matrix, the spheroidization of eutectic $\mathrm{Mg}_{2} \mathrm{Si}$ phase and the grains growth of $\alpha-\mathrm{Mg}$ phase.
It was reported that the hardness increment in binary $\mathrm{Mg}$-Sn alloys is relatively low $(\Delta \mathrm{HV} \approx 10 \mathrm{HV})$ and hardness of as-cast $\mathrm{Mg}$-Sn alloys aged at $200{ }^{\circ} \mathrm{C}$ is in the range from 45 to $55 \mathrm{HV}[14,23]$. In this work, similar results of hardness increment were obtained for aged Mg-7Sn alloy $(\Delta \mathrm{HV}=11 \mathrm{HV})(\mathrm{Tab} .2)$. The age hardening behavior of 

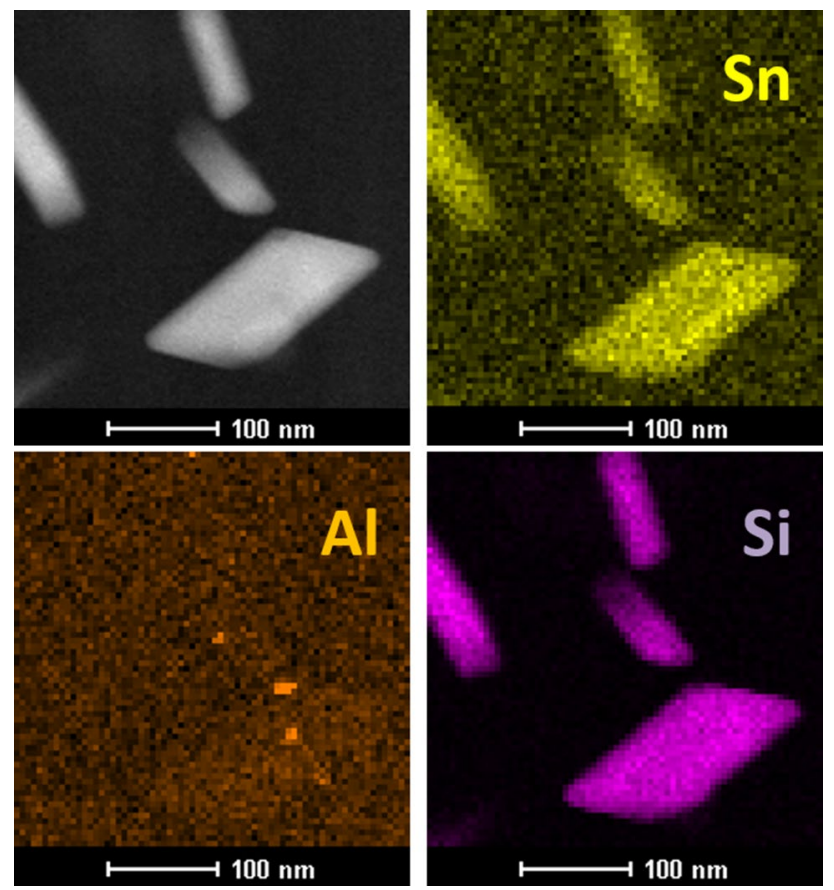

Fig. 6 TEM dark image of $\mathrm{Mg}_{2} \mathrm{Sn}$ precipitates and the corresponding EDX maps showing the elemental distribution of $\mathrm{Si}, \mathrm{Al}$, and $\mathrm{Sn}$

tested alloys (Fig. 8) indicates that the silicon and aluminum additions enhance the hardness increment of $\mathrm{Mg}$-7 Sn alloy. The hardness growth is comparable for $\mathrm{Mg}-7 \mathrm{Sn}-1 \mathrm{Si}$ and Mg-7Sn-5Si alloys ( $\Delta \mathrm{HV} \approx 15-16 \mathrm{HV})$, while Al caused a further increase in hardness increment $(\Delta \mathrm{HV} \approx 19 \mathrm{HV})$. Changes in the hardness of tested alloys result from the reduction of the $\mathrm{Mg}_{2} \mathrm{Sn}$ precipitates size and the increase in the number precipitates. Summary of ageing response of alloys at $250{ }^{\circ} \mathrm{C}$ is shown in Table 2 .

The tensile properties including ultimate tensile strength (UTS), yield strength (YS) and elongation $(\varepsilon)$ of as-cast and aged alloys are listed in Table 3. The sand-cast Mg-7Sn alloy exhibits the lowest tensile strength, yield strength and the best elongation. T6 heat treatment of this alloy contributes to a significant improvement of UTS, YTS and elongation, however, the YTS values are still insufficient to practical applications. The relatively low mechanical properties of the Mg-7Sn alloy result from coarse-grained structure due to the low cooling rate in the sand molds. Addition of $1 \mathrm{wt} \%$ silicon to Mg-7Sn alloy increased its mechanical properties, which can be explained by the reduction in $\alpha-\mathrm{Mg}$ grain size and via the formation of a greater number of finer $\mathrm{Mg}_{2} \mathrm{Sn}$ precipitates. The $\mathrm{Mg}_{2} \mathrm{Si}$ eutectic phase, which has partially coagulated after solution heat treatment, should not significantly improve the strength due to its size and low efficiency in blocking dislocations. However, it may contribute to hindering grain boundary slip. Existence in the microstructure the $\mathrm{Mg}_{2} \mathrm{Si}$ primary crystals (alloys with $5 \% \mathrm{Si}$ ), which is characterized by unfavorable morphology and large size, resulted in a significant deterioration in strength, despite lower grain size of $\alpha-\mathrm{Mg}$ solid solution. The $\mathrm{Al}$ addition promotes the improvement of mechanical properties due to the formation of the finer precipitates of the $\mathrm{Mg}_{2} \mathrm{Sn}$ phase and the solid solution strengthening. It has been shown that aluminum significantly strengthens the $\alpha-\mathrm{Mg}$ solid solution due to high solubility in $\mathrm{Mg}$ at ambient temperature and large atomic size misfit (11\%) [27].

The creep behavior of the peak-aged alloys was studied at temperatures between 200 and $300{ }^{\circ} \mathrm{C}$ under applied stresses between 15 and $60 \mathrm{MPa}$. The typical creep curves obtained at a temperature of $200{ }^{\circ} \mathrm{C}$ and a stress of $30 \mathrm{MPa}$ are shown in Fig. 9. From these creep curves, the primary and secondary creep stages can be clearly distinguished. The steady-state creep rate $\dot{\varepsilon}$ was calculated by measuring the slope of the steady-state stage of the curves and results are presented in Table 4. For comparison, the creep results of sand cast Mg-3Zn-3RE-0.7Zr (EZ33) and Mg-Al-Ca-Sr alloys are also included. The sand-cast Mg-7Sn alloy exhibits a very poor creep resistance at the stress of $30 \mathrm{MPa}$ and at temperatures of $200{ }^{\circ} \mathrm{C}$ and of $250{ }^{\circ} \mathrm{C}$, therefore this alloy was not selected to further creep tests at higher stresses and temperatures. When $1 \% \mathrm{Si}$ is added to the $\mathrm{Mg}-7 \mathrm{Sn}$ alloy, a significant improvement in creep resistance at $200{ }^{\circ} \mathrm{C}$ temperature range is observed. In comparison to alloys with 5\% $\mathrm{Si}(\mathrm{Mg}-7 \mathrm{Sn}-5 \mathrm{Si}, \mathrm{Mg}-7 \mathrm{Sn}-5 \mathrm{Si}-2 \mathrm{Al})$ the $\mathrm{Mg}-7 \mathrm{Sn}-1 \mathrm{Si}$ alloy is characterized by better creep resistance at a temperature of $200{ }^{\circ} \mathrm{C}$ and at stresses $30-45 \mathrm{MPa}$. However, at a temperature of $250{ }^{\circ} \mathrm{C}$ the Si-rich alloys exhibit a lower creep rate and creep strain. In comparison to the sand-cast $\mathrm{Mg}-\mathrm{Al}$ $\mathrm{Ca}-\mathrm{Sr}$ and EZ33 alloys, which were crept at $60 \mathrm{MPa}$, the creep properties of $\mathrm{Mg}$-Sn-Si alloys tested in this work are clearly inferior.

The power-law equation is often used to evaluate creep mechanisms in magnesium alloys and it can be written as follows [2]:

$\dot{\varepsilon}=A \sigma^{n} \exp \left(\frac{-Q_{s}}{\mathrm{RT}}\right)$

where $A$ is a constant, $n$ is the apparent stress exponent, $R$ is the gas constant, and $Q_{\mathrm{s}}$ is the apparent activation energy.

The $n$ and $Q_{c}$ parameters can be indirectly used to determine the dominant creep deformation mechanism for material in specific ranges of stress and temperature [2]. In the case of Mg-7Sn-1Si alloy, the exponent values of $n$ were determined only in the range of 30-45 MPa due to the short duration of creep tests at $60 \mathrm{MPa}$. These values are 5.7 and 7.4 at temperatures of $200{ }^{\circ} \mathrm{C}$ and $250{ }^{\circ} \mathrm{C}$, respectively (Table 5). Similar values of $\mathrm{n}$ parameters were obtained for alloys with $5 \% \mathrm{Si}$ content, however, in the stress range of 30-60 MPa. Thus it can be concluded that the dislocation 

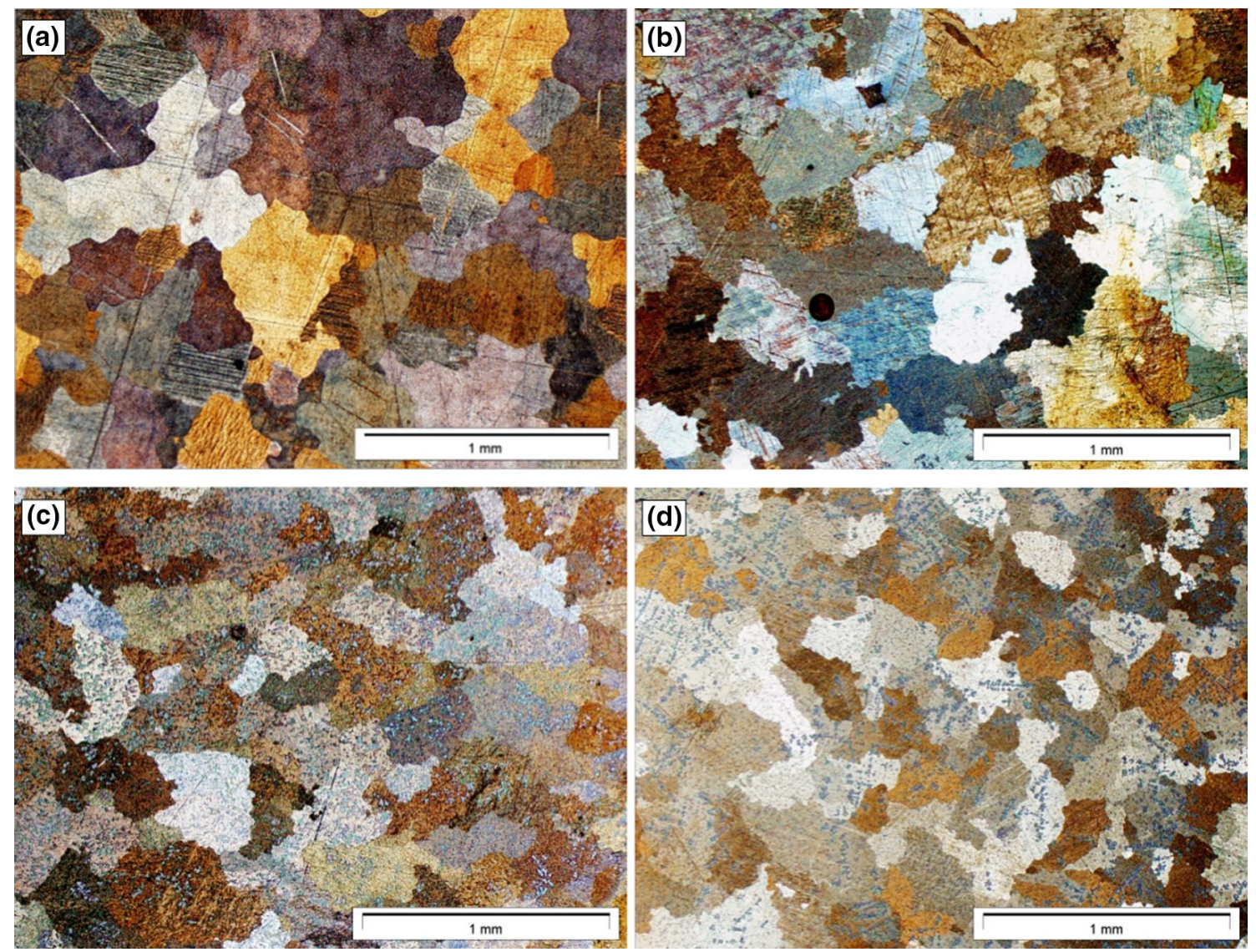

Fig. 7 LM micrographs with the revealed the $\alpha$-Mg grains of the peak-aged alloys. Mg-7Sn alloy (a), Mg-7Sn-1Si alloy (b), Mg-7Sn-5Si alloy (c), Mg-7Sn-5Si-2Al alloy (d)

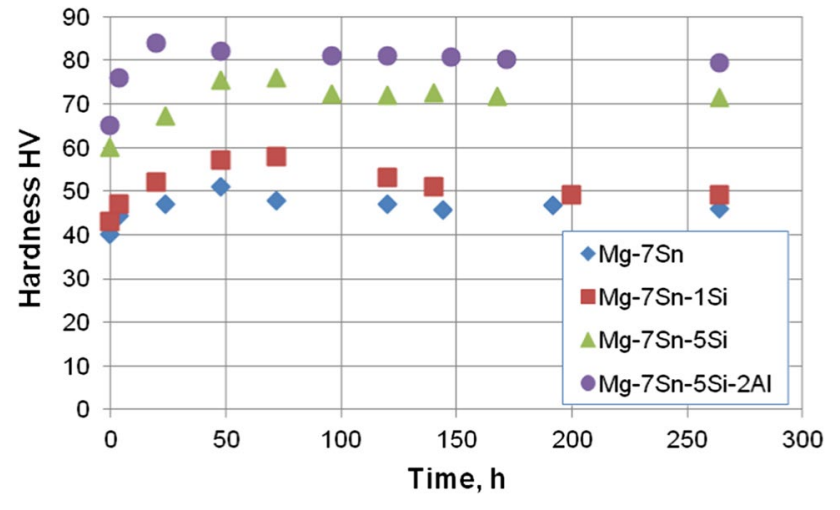

Fig. 8 Age hardening curves of the tested alloys at $250{ }^{\circ} \mathrm{C}$

climbing and gliding can be regarded as a rate-controlling mechanism in these alloys [28-34].

It should be mentioned here that the $n$ exponent values may be overestimated. Tested alloys consist of precipitates of $\mathrm{Mg}_{2} \mathrm{Sn}$ phase inside the $\alpha-\mathrm{Mg}$ matrix, therefore, in determining the exponent $\mathrm{n}$, the threshold stresses $\left(\sigma_{0}\right)$ should also be included in the calculation. However, correct determination
Table 3 Mechanical properties at an ambient temperature of as-cast and peak-aged alloys

\begin{tabular}{lllll}
\hline & Condition & UTS, MPa & YTS, MPa & El, \% \\
\hline Mg-7Sn & As-cast & $87(11)$ & $41(9)$ & $3.4(0.3)$ \\
& Aged at & $127(8)$ & $66(8)$ & $3.8(0.2)$ \\
& $250{ }^{\circ} \mathrm{C} / 48 \mathrm{~h}$ & & & \\
Mg-7Sn-1Si & As-cast & $111(23)$ & $102(13)$ & $1.8(0.1)$ \\
& Aged at & $145(11)$ & $115(8)$ & $2.8(0.2)$ \\
& $250{ }^{\circ} \mathrm{C} / 72 \mathrm{~h}$ & & & \\
Mg-7Sn-5Si & As-cast & $99(14)$ & $80(9)$ & $1.9(0.1)$ \\
& Aged at & $115(4)$ & $101(6)$ & $1.7(0.1)$ \\
& $250^{\circ} \mathrm{C} / 72 \mathrm{~h}$ & & & \\
Mg-7Sn-5Si- & As-cast & $95(16)$ & $74(14)$ & $2.4(0.3)$ \\
$2 \mathrm{Al}$ & Aged at & $130(8)$ & $108(5)$ & $2.9(0.2)$ \\
& $250{ }^{\circ} \mathrm{C} / 20 \mathrm{~h}$ & & & \\
\hline
\end{tabular}

In brackets the standard deviation is given

of the threshold stress is possible if the experimental data covers a sufficiently large range of creep rates and in case of tested alloys the creep rate range is not large enough. On the other hand, stress exponent $n$ is not significantly greater than 


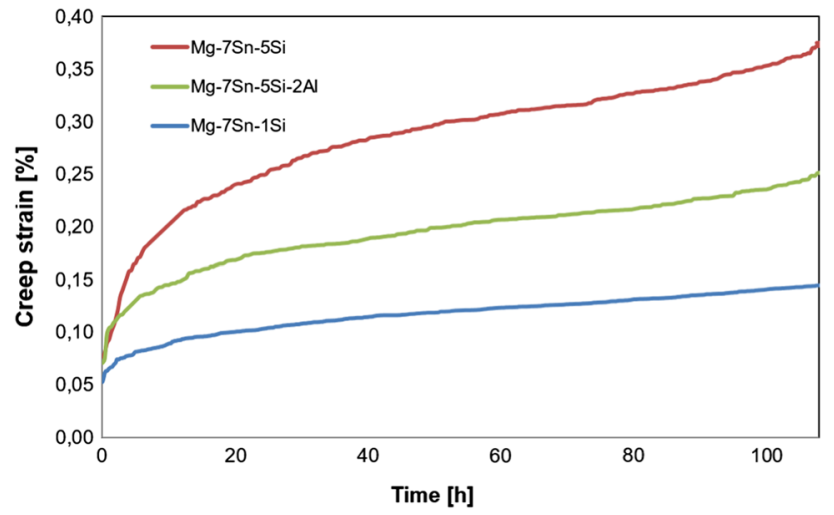

Fig. 9 Examples of creep curves at a temperature of $200{ }^{\circ} \mathrm{C}$ and stress of $30 \mathrm{MPa}$

expected, which may indicate that the interaction between $\mathrm{Mg}_{2} \mathrm{Sn}$ precipitates and dislocations is not strong.

The activation energy of creep deformation $\left(Q_{c}\right)$ for the most thermally activated processes in $\mathrm{Mg}$ are: lattice diffusion $(135 \mathrm{~kJ} / \mathrm{mole})$, pipe diffusion $(92 \mathrm{~kJ} / \mathrm{mole})$ and GB diffusion (60-80 kJ/mole). $Q_{c}$ values for dislocational processes in $\mathrm{Mg}$ alloys are dislocation climb $(135 \mathrm{~kJ} / \mathrm{mole})$ and cross-slip ( $200 \mathrm{~kJ} / \mathrm{mole})$ [10]. The activation energy $\left(Q_{c}\right)$ determined at $45 \mathrm{MPa}$ for $\mathrm{Mg}-7 \mathrm{Sn}-1 \mathrm{Si}$ alloy is about $139 \mathrm{~kJ} / \mathrm{mole}$ between 200 and $250{ }^{\circ} \mathrm{C}$ (Table 5), therefore, dislocation climb controlled by lattice diffusion can be the main mechanism the creep deformation in $\mathrm{Mg}-7 \mathrm{Sn}-1 \mathrm{Si}$ alloy at applied stresses $45 \mathrm{MPa}$ and a temperature range of $200-250{ }^{\circ} \mathrm{C}$. Activation energy $Q_{c}$ of $\mathrm{Mg}-7 \mathrm{Sn}-5 \mathrm{Si}$ alloy at these creep conditions (Table $5, O_{c} \approx 123 \mathrm{~kJ} / \mathrm{mole}$ ) is lower than that of the Mg-7Sn-1Si alloy which may suggest a decreasing contribution of lattice diffusion and an increasing contribution of pipe diffusion to total creep deformation. The $Q_{c}$ value of Mg-7Sn-5Si-2Al (Table 5, $O_{c} \approx 87 \mathrm{~kJ} /$ mole) indicate that creep deformation mechanism could be dislocation climb controlled by pipe diffusion, however, the grain boundary diffusion also has a significant contribution to the total deformation of the alloy during creep in tested conditions.

The fracture surface of the alloy having a lower silicon content $(\mathrm{Mg}-7 \mathrm{Sn}-1 \mathrm{Si})$ after creep at $250{ }^{\circ} \mathrm{C} / 45 \mathrm{MPa}$

Table 4 The creep properties of the peak-aged alloys, $\sigma$-stress, $\dot{\varepsilon}$-steady-state creep rate, $\varepsilon$ —creep strain at $110 \mathrm{~h}$ or at the break, $\mathrm{t}-\mathrm{creep}$ life

\begin{tabular}{|c|c|c|c|c|c|c|c|c|c|c|}
\hline \multirow[t]{2}{*}{ Alloy } & \multirow[t]{2}{*}{$\sigma[\mathrm{MPa}]$} & \multicolumn{3}{|l|}{$200^{\circ} \mathrm{C}$} & \multicolumn{3}{|l|}{$250^{\circ} \mathrm{C}$} & \multicolumn{3}{|l|}{$300{ }^{\circ} \mathrm{C}$} \\
\hline & & $\dot{\varepsilon}[1 / \mathrm{s}]$ & $\varepsilon[\%]$ & $t[\mathrm{~h}]$ & $\dot{\varepsilon}[1 / \mathrm{s}]$ & $\varepsilon[\%]$ & $t[\mathrm{~h}]$ & $\dot{\varepsilon}[1 / \mathrm{s}]$ & $\varepsilon[\%]$ & $t[\mathrm{~h}]$ \\
\hline $\mathrm{Mg}-7 \mathrm{Sn}$ & 30 & $4.11 \cdot 10^{-7}$ & 5.1 & 16 & $1.42 \cdot 10^{-5}$ & 6.7 & 1 & & & \\
\hline \multirow[t]{3}{*}{$\mathrm{Mg}-7 \mathrm{Sn}-1 \mathrm{Si}$} & 15 & - & - & - & - & - & - & $1.01 \cdot 10^{-6}$ & 15.4 & 45 \\
\hline & 30 & $2.79 \cdot 10^{-9}$ & 0.15 & $>110$ & $4.06 \cdot 10^{-8}$ & 3.4 & $>110$ & - & - & - \\
\hline & 45 & $2.77 \cdot 10^{-8}$ & 2.5 & $>110$ & $8.12 \cdot 10^{-7}$ & 9.3 & 32 & - & - & - \\
\hline \multirow[t]{4}{*}{ Mg-7Sn-5Si } & 15 & - & - & - & - & - & - & $1.25 \cdot 10^{-8}$ & 1.54 & $>110$ \\
\hline & 30 & $3.81 \bullet 10^{-9}$ & 0.38 & $>110$ & $3.67 \cdot 10^{-8}$ & 3.8 & $>110$ & - & - & - \\
\hline & 45 & $3.40 \cdot 10^{-8}$ & 2.7 & $>110$ & $6.73 \cdot 10^{-7}$ & 8.9 & 40 & - & - & - \\
\hline & 60 & $1.65 \cdot 10^{-7}$ & 5.3 & 72 & $5.70 \bullet 10^{-6}$ & 6.8 & 6 & - & - & - \\
\hline \multirow[t]{4}{*}{ Mg-7Sn-5Si-2Al } & 15 & - & - & - & - & - & - & $9.58 \cdot 10^{-9}$ & 0.64 & $>110$ \\
\hline & 30 & $2.43 \cdot 10^{-9}$ & 0.26 & $>110$ & $9.85 \cdot 10^{-9}$ & 1.0 & $>110$ & - & - & - \\
\hline & 45 & $3.11 \cdot 10^{-8}$ & 3.2 & $>110$ & $2.59 \cdot 10^{-7}$ & 11.8 & $>110$ & - & - & - \\
\hline & 60 & $1.94 \cdot 10^{-7}$ & 8.9 & $>110$ & $2.43 \cdot 10^{-6}$ & 8.5 & 12 & - & - & - \\
\hline Mg-3Zn-3RE-0.7Zr (EZ33) & 60 & $6.5 \cdot 10^{-9}$ & $0.90 *$ & $>100$ & - & - & - & - & - & - \\
\hline Mg-9Al-3Ca-0,8Sr & 60 & $4.43 \cdot 10^{-9}$ & $0.64 *$ & $>100$ & - & - & - & - & - & - \\
\hline
\end{tabular}

Creep strain at $100 \mathrm{~h}$

Table 5 The apparent stress exponent $n$ and the apparent activation energy $Q_{\mathrm{s}}$ of tested alloys

\begin{tabular}{lllllll}
\hline Alloy & $\begin{array}{l}\text { Temperature, } \\
{\left[{ }^{\circ} \mathrm{C}\right]}\end{array}$ & $\begin{array}{l}\text { Stress range, } \\
{[\mathrm{MPa}]}\end{array}$ & $n$ & Stress, $[\mathrm{MPa}]$ & $\begin{array}{l}\text { Temperature } \\
\text { range, }\left[{ }^{\circ} \mathrm{C}\right]\end{array}$ & $\begin{array}{l}Q_{s}, \\
\mathrm{~kJ} / \mathrm{mol}\end{array}$ \\
\hline Mg-7Sn-1Si & 200 & $30-45$ & 5.7 & 45 & $200-250$ & 139 \\
& 250 & $30-45$ & 7.4 & & & \\
Mg-7Sn-5Si & 200 & $30-60$ & 5.4 & 45 & $200-250$ & 123 \\
& 250 & $30-60$ & 7.3 & & & \\
Mg-7Sn-5Si-2Al & 200 & $30-60$ & 6.3 & 45 & & \\
& 250 & $30-60$ & 8.0 & & & \\
\hline
\end{tabular}


(Fig. 10) exhibits ductile and brittle characteristics. The presence of dimples on the fracture surface indicates high ductility of $\mathrm{Mg}$-7Sn-1Si alloy during creep under these conditions $\left(250{ }^{\circ} \mathrm{C} / 45 \mathrm{MPa}\right)$. It is well known that magnesium and its alloys exhibit brittle fracture at ambient temperature due to the low number of slip systems, therefore, the domination of a ductile surface indicates the activation of additional slip systems (prismatic and pyramidal slip systems). In combination with the results of creep tests (Table 4), this leads to the conclusion that the plate-like precipitates of $\mathrm{Mg}_{2} \mathrm{Sn}$ phase within the $\alpha-\mathrm{Mg}$ grains are not sufficiently effective in blocking dislocations moving in thermally activated slip systems which results from the orientation relationship: $(0001)_{\alpha-\mathrm{Mg}} / /(110)_{\mathrm{Mg} 2 \mathrm{Sn}},[11-20]_{\alpha-\mathrm{Mg}} / /[001]_{\mathrm{Mg} 2 \mathrm{Sn}}$. Effectiveness in blocking dislocations is also reduced as a result of spheroidization of $\mathrm{Mg}_{2} \mathrm{Sn}$ precipitates at the elevated temperature (Fig. 11), thus their size and inter-particle

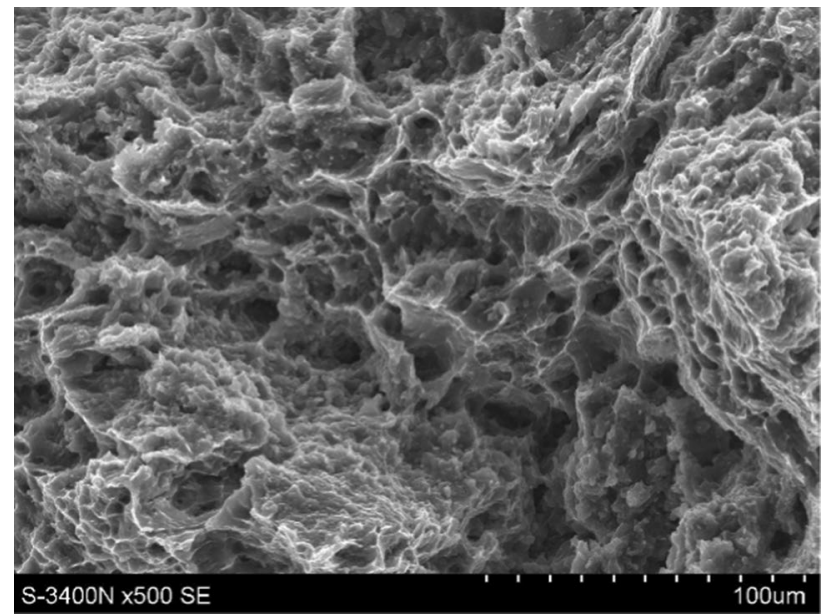

Fig. 10 SEM image of the fracture surface of the crept Mg-7Sn-1Si alloy at $250{ }^{\circ} \mathrm{C} / 45 \mathrm{MPa}$ spacing are increased. Moreover, these precipitates break during the creep (Fig. 12a) and contribute to the formation of voids within the $\alpha-\mathrm{Mg}$ and, consequently, to a reduction in strength. The presence of hard $\mathrm{Mg}_{2} \mathrm{Si}$ phase at the interdendritic regions favors stress concentration at grain boundaries and nucleation of cracks at the $\alpha-\mathrm{Mg} / \mathrm{Mg}_{2} \mathrm{Si}$ interface (Fig. 13). These cracks propagate along the grain boundary and produce brittle fracture. In the Si-rich alloys the cracks propagate both along the grain boundaries and inside the $\mathrm{Mg}_{2} \mathrm{Si}$ primary crystals (Fig. 12b). Moreover, the fracture surfaces of the crept Si-rich alloys exhibit features of ductile fracture indicating the additional slip systems are activated.

Summarizing the results of the research on creep it can be concluded that sand-cast and heat-treated (T6) Mg-Sn alloys are characterized by low creep resistance at $200{ }^{\circ} \mathrm{C}$. The low creep resistance of $\mathrm{Mg}$ alloys containing up to $5 \% \mathrm{Sn}$ is the result of the formation of large precipitates of the equilibrium $\mathrm{Mg}_{2} \mathrm{Sn}$ phase, their unfavorable crystallographic orientation relative to the $\alpha-\mathrm{Mg}$ matrix, tendency to coagulate at elevated temperature and the lack of strengthening of grain boundaries. The addition of $1 \% \mathrm{Si}$ significantly improves creep resistance at $200{ }^{\circ} \mathrm{C}$ of $\mathrm{Mg}$-Sn alloys due to the refinement of the $\mathrm{Mg}_{2} \mathrm{Sn}$ precipitates and especially the formation of the $\mathrm{Mg}_{2} \mathrm{Si}$ phase at interdendritic regions. The presence of the eutectic $\mathrm{Mg}_{2} \mathrm{Si}$ phase is conducive to strengthening the grain boundaries of the $\alpha-\mathrm{Mg}$ solid solution, however, on the other hand, the solution heat treatment causes a partial spheroidization of the $\mathrm{Mg}_{2} \mathrm{Si}$ phase, which reduces the effectiveness of strengthening the grains boundaries. The main creep mechanism of the Mg-7Sn-1Si alloy is dislocation climb controlled by lattice diffusion. Increasing the silicon content to $5 \%$ resulted in improved creep resistance at $250{ }^{\circ} \mathrm{C}$ and a change in creep mechanisms. The appearance of $\mathrm{Mg}_{2} \mathrm{Si}$ primary crystals, further the refinement $\mathrm{Mg}_{2} \mathrm{Sn}$ precipitates and refinement of $\alpha-\mathrm{Mg}$ grains caused that pipe diffusion has a greater contribution to controlling dislocation climb during
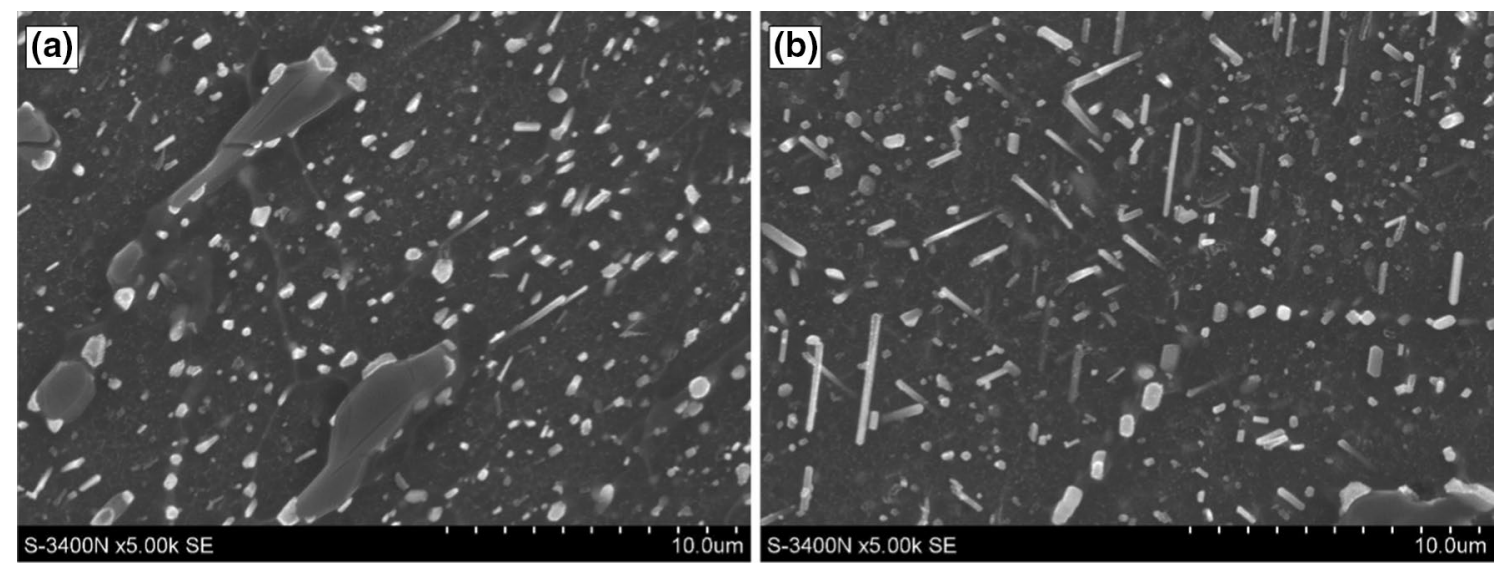

Fig. 11 The $\mathrm{Mg}_{2} \mathrm{Sn}$ precipitates in peak-aged $\mathrm{Mg}-7 \mathrm{Sn}-5 \mathrm{Si}$ alloy after creep at $300{ }^{\circ} \mathrm{C}$ and $15 \mathrm{MPa}$ 

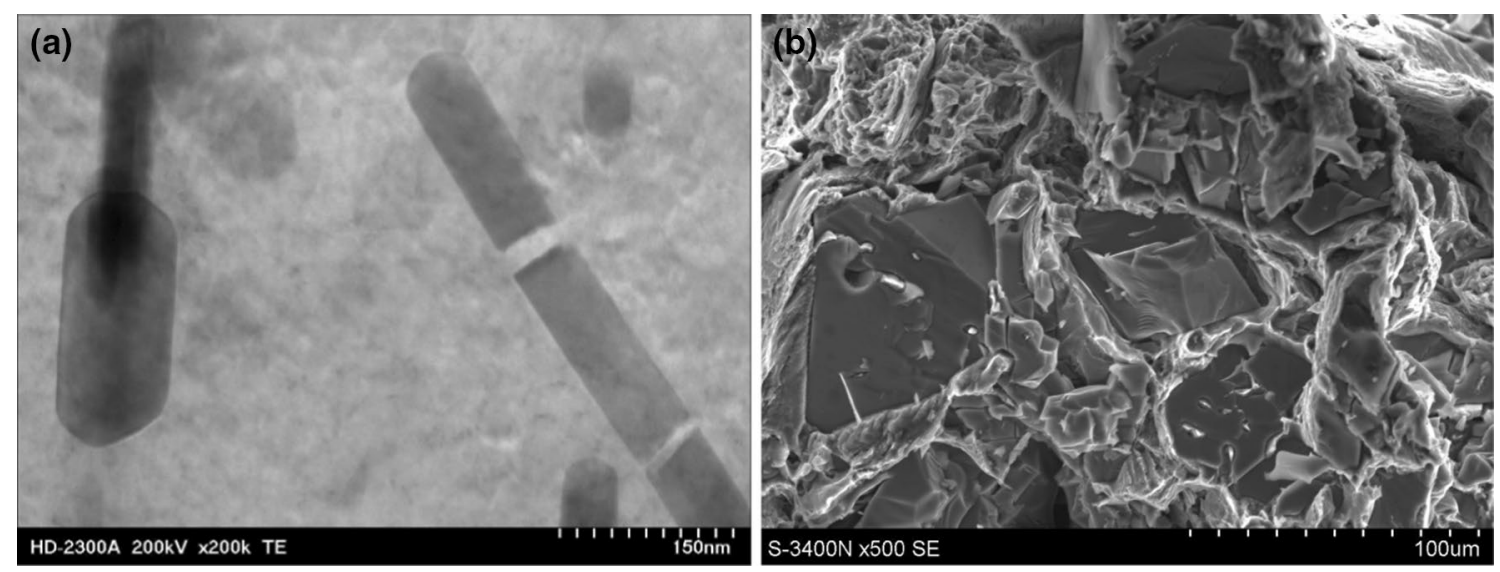

Fig. 12 Cracked the lath-like precipitates of $\mathrm{Mg}_{2} \mathrm{Sn}$ phase in $\mathrm{Mg}-7 \mathrm{Sn}-5 \mathrm{Si}-2 \mathrm{Al}$ alloy after creep at $250{ }^{\circ} \mathrm{C} / 30 \mathrm{MPa}(\mathbf{a})$, SEM image of the fracture surface of the crept $\mathrm{Mg}-7 \mathrm{Sn}-5 \mathrm{Si}$ alloy at $250{ }^{\circ} \mathrm{C} / 45 \mathrm{MPa}(\mathbf{b})$
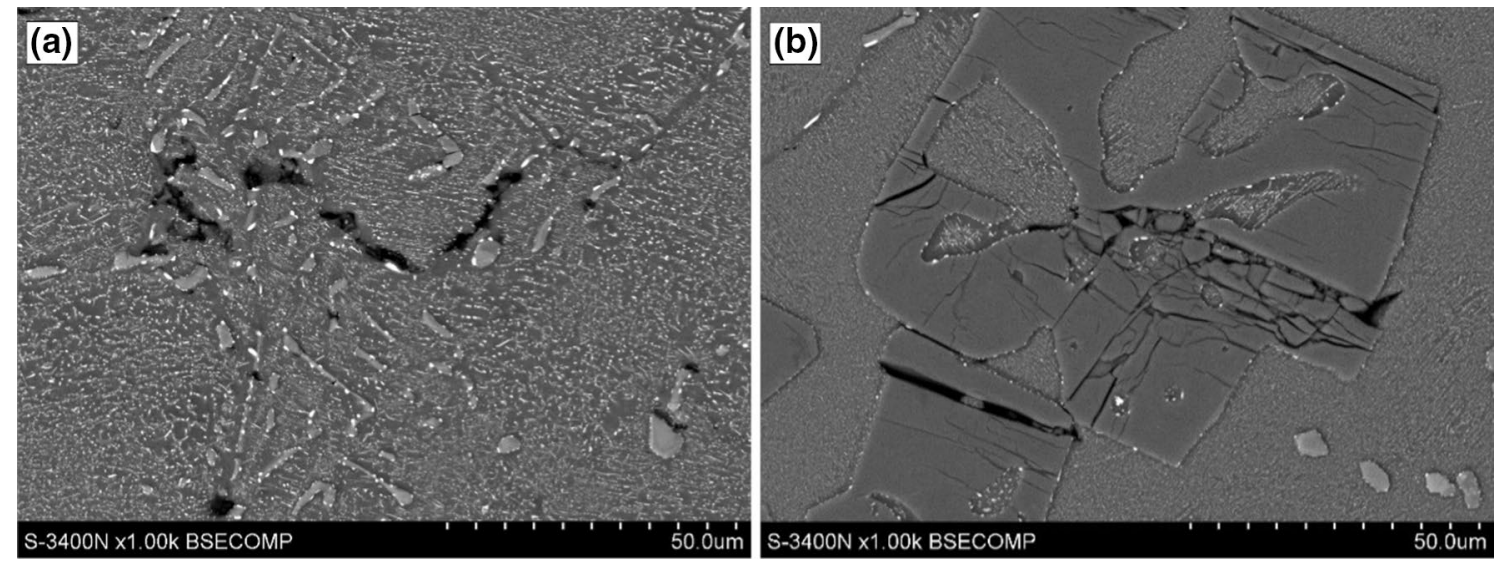

Fig. 13 Cracks at the grain boundaries in $\mathrm{Mg}-7 \mathrm{Sn}-1 \mathrm{Si}$ alloy after creep at $250{ }^{\circ} \mathrm{C} / 45 \mathrm{MPa}$ (a), cracks inside the $\mathrm{Mg}_{2} \mathrm{Si}$ primary crystals in $\mathrm{Mg}-7 \mathrm{Sn}-5 \mathrm{Si}$ alloy after creep at $250{ }^{\circ} \mathrm{C} / 30 \mathrm{MPa}(\mathbf{b})$

creep at $45 \mathrm{MPa}$ in the $\mathrm{Mg} 7 \mathrm{Sn}-5 \mathrm{Si}$ alloy. In case of Mg-7Sn$5 \mathrm{Si}-2 \mathrm{Al}$ alloy, in which the refinement of the $\mathrm{Mg}_{2} \mathrm{Sn}$ precipitates is more significant than in the Mg-7Sn-5Si alloy, the obtained $Q_{c}$ value $(87 \mathrm{~kJ} / \mathrm{mol})$ is between $80 \mathrm{~kJ} / \mathrm{mol}(\mathrm{GBD})$ and $92 \mathrm{~kJ} / \mathrm{mol}$ (pipe diffusion), which suggest a significant contribution of both grain boundaries diffusion and diffusion along with the dislocation cores in the creep deformation of aged Mg-7Sn-1Si alloy. The greater contribution of grain boundary diffusion may also result from the lower $\alpha-\mathrm{Mg}$ grain size of the Mg-7Sn-5Si-2Al alloy.

Generally, slightly better creep resistance of $\mathrm{Mg}-7 \mathrm{Sn}-5 \mathrm{Si}-$ $2 \mathrm{Al}$ alloy than $\mathrm{Mg}-7 \mathrm{Sn}-5 \mathrm{Si}$ is a consequence of the formation of a larger number the plate-like $\mathrm{Mg}_{2} \mathrm{Sn}$ precipitates, which are characterized by a lower size and inter-particle spacing. Moreover, precipitates of the $\mathrm{Mg}_{2} \mathrm{Sn}$ phase exhibits different morphologies (lath, polygon and plate) with different orientation relationships in the aged condition. It is possible that the $\mathrm{Al}$ addition promotes the formation of polygonal $\mathrm{Mg}_{2} \mathrm{Sn}$ precipitates, which possibly have better-strengthening effect than lath and plate-shaped $\mathrm{Mg}_{2} \mathrm{Sn}$ precipitates. In the studied alloy the $\mathrm{Al}$, besides to such effects as refining the precipitates and partly changing their morphology, dissolves in the $\alpha-\mathrm{Mg}$ matrix causing the effect of solution strengthening. However, in case of solid solution $\mathrm{Al}$ in $\mathrm{Mg}$ strengthening effects are anisotropic. According to [27] $\mathrm{Al}$ increases the critical resolved shear stress (CRSS) for basal slip proportional to the $\mathrm{Al}$ concentration and lowers the CRSS for prismatic slip, thus the strengthening effect caused by the presence of $\mathrm{Al}$ in $\mathrm{Mg}$ may not be significant at elevated temperatures.

The Mg-7Sn-1Si alloy exhibits better creep resistance at $200{ }^{\circ} \mathrm{C}$ and $30-45 \mathrm{MPa}$ than Si-rich alloys, while at $250{ }^{\circ} \mathrm{C}$ creep properties of Si-rich alloys become better. It seems that the main reason is the presence of $\mathrm{Mg}_{2} \mathrm{Si}$ primary crystals contributing to the significant embrittlement of $\mathrm{Mg}$ alloys at ambient temperature. At $200{ }^{\circ} \mathrm{C}$ (about $0.3 \mathrm{Tm}$ ), the plasticity of Si-rich alloys is still insufficient, which leads to the formation of cracks at the $\alpha-\mathrm{Mg} / \mathrm{Mg}_{2} \mathrm{Si}_{\mathrm{p}}$ interface. At 
temperatures above $250{ }^{\circ} \mathrm{C}$, thermally stable and hard $\mathrm{Mg}_{2} \mathrm{Si}$ primary crystals inhibit displacement and rotation of $\alpha-\mathrm{Mg}$ grains, and the $\alpha-\mathrm{Mg} / \mathrm{Mg}_{2} \mathrm{Si}_{\mathrm{p}}$ stress generated at the interface is less than at lower temperatures, hence the cracking process begins at a later period of creep.

In comparison to EZ33 magnesium alloy the creep properties at a temperature of $200{ }^{\circ} \mathrm{C}$ and a stress of $60 \mathrm{MPa}$ of the tested $\mathrm{Mg}$-Si-Sn alloys are still lower. However, at lower stresses around of $30 \mathrm{MPa}, \mathrm{Mg}-\mathrm{Sn}-\mathrm{Si}$ alloys may be an alternative to some alloys containing rare earth metals. At $250{ }^{\circ} \mathrm{C}$, tested $\mathrm{Mg}$-Sn-Si alloys also show clearly lower creep resistance compared to the commercial WE series magnesium alloys [35].

\section{Conclusions}

1. Microstructure of sand-cast $\mathrm{Mg}$-Sn alloys consists of $\alpha-\mathrm{Mg}$ solid solution and $\mathrm{Mg}_{2} \mathrm{Sn}$ phase. Addition of $\mathrm{Si}$ to $\mathrm{Mg}-\mathrm{Sn}$ alloy leads to the formation of eutectic $\mathrm{Mg}_{2} \mathrm{Si}$ phase and primary crystals of $\mathrm{Mg}_{2} \mathrm{Si}$ phase. The addition of $2 \% \mathrm{Al}$ dissolved in the $\alpha-\mathrm{Mg}$ matrix and does not create new intermetallic phases.

2. Solution heat treatment at $500{ }^{\circ} \mathrm{C}$ for $8 \mathrm{~h}$ causes dissolution of the $\mathrm{Mg}_{2} \mathrm{Sn}$ phase in the $\alpha-\mathrm{Mg}$ matrix. The eutectic $\mathrm{Mg}_{2} \mathrm{Si}$ phase undergoes spheroidization and the morphology of the $\mathrm{Mg}_{2} \mathrm{Si}$ primary crystals does not change during solution heat treatment at $500{ }^{\circ} \mathrm{C}$.

3. The plate-like, lath-shaped and polygonal precipitates of $\mathrm{Mg}_{2} \mathrm{Sn}$ phase are formed after ageing of these alloys at a temperature of $250{ }^{\circ} \mathrm{C}$. The additions o Si and $\mathrm{Al}$ to $\mathrm{Mg}$-Sn alloys promote the refinement of $\mathrm{Mg}_{2} \mathrm{Sn}$ precipitates.

4. Tensile properties of as-cast alloys are low. The use of heat treatment consisting of solid solution treatment at $500{ }^{\circ} \mathrm{C}$ and aging at $250{ }^{\circ} \mathrm{C}$ increases the tensile properties.

5. The sand-cast $\mathrm{Mg}-7 \mathrm{Sn}-1 \mathrm{Si}$ and $\mathrm{Mg} 7 \mathrm{Sn}-5 \mathrm{Si}$ alloys exhibits good creep properties up to a temperature of $200{ }^{\circ} \mathrm{C}$ and stress of $30 \mathrm{MPa}$. Sand-cast $\mathrm{Mg} 7 \mathrm{Sn}-5 \mathrm{Si}-2 \mathrm{Al}$ alloy has better creep resistance up to $30 \mathrm{MPa}$ and $250{ }^{\circ} \mathrm{C}$, and also shows good creep characteristics at $15 \mathrm{MPa}$ and $300{ }^{\circ} \mathrm{C}$

6. The dominant creep mechanism in the Mg-7Sn-1Si alloy at stress of $45 \mathrm{MPa}$ and in the temperature range $200-250{ }^{\circ} \mathrm{C}$ is the dislocation climb controlled by lattice diffusion. In the case of the Mg-7Sn-5Si alloy, the contribution of pipe diffusion increases during dislocation climb, while for the $\mathrm{Mg}-7 \mathrm{Sn}-5 \mathrm{Si}-2 \mathrm{Al}$ alloy, dislocation climb controlled by pipe diffusion, as well as by grain boundary diffusion appears to be the main mechanism of creep deformation.
Acknowledgements This work was supported by the National Science Centre under the project UMO-2011/03/D/ST8/03869. The author is grateful to Ph.D B. Chmiela (Silesian University of Technology, Katowice, Poland) and PhD P. Skupień (IMŻ Gliwice, Poland) for their assistance and useful discussion.

Funding This study was supported by the National Science Center Poland (Narodowe Centrum Nauki) under the Project UMO-2011/03/D/ ST8/03869.

Availability of data and material Original data is available. Materials (alloys) are not available.

\section{Compliance with ethical standards}

Conflict of interest The author declares that he has no conflict of interest.

Open Access This article is licensed under a Creative Commons Attribution 4.0 International License, which permits use, sharing, adaptation, distribution and reproduction in any medium or format, as long as you give appropriate credit to the original author(s) and the source, provide a link to the Creative Commons licence, and indicate if changes were made. The images or other third party material in this article are included in the article's Creative Commons licence, unless indicated otherwise in a credit line to the material. If material is not included in the article's Creative Commons licence and your intended use is not permitted by statutory regulation or exceeds the permitted use, you will need to obtain permission directly from the copyright holder. To view a copy of this licence, visit http://creativecommons.org/licenses/by/4.0/.

\section{References}

1. Mo N, Tan Q, Bermingham M, Huang Y, Dieringa H, Hort N, Zhang M-X. Current development of creep-resistant magnesium cast alloys: a review. Mater Design. 2018;155:422-42.

2. Luo AA. Recent magnesium alloy development for elevated temperature applications. Int Mater Rev. 2004;49:13-30.

3. Friedrich H, Mordike BL. Magnesium technology, metallurgy design data, applications. Berlin Heidelberg: Springer-Verlag; 2006.

4. Baril E, Labelle P, Pekguleryuz M. Elevated temperature MgAl-Sr: creep resistance, mechanical properties, and microstructure. J Met. 2003;55:34-9.

5. Ninomiya R, Ojiro T, Kubota K. Improved heat resistance of $\mathrm{Mg}$-Al alloys by the $\mathrm{Ca}$ addition. Acta Metall Mater. 1995;43:669-74.

6. Pettersen G, Westengen H, Høier R, Lohne O. Microstructure of a pressure die cast magnesium-4wt.\% aluminum alloy modified with rare earth additions. Mater Sci Eng A. 1996;207:115-20.

7. Podosek M, Lorimer G. The influence of intergranular microstructure of Mg-Zn-RE alloys on properties at elevated temperatures. Arch Metall. 2000;45:47-55.

8. P. Lyon, Processing Review for Elektron WE43, Launch of Elektron 21, Paris\&London, November 2003

9. Celikin M, Kaya AA, Pekguleryuz M. The role of $\alpha-M n$ precipitation on the creep mechanisms of Mg-Sr-Mn. Mater Sci Eng A. 2012:534:129-41.

10. M. Celikin, The creep behaviour of magnesium-manganese based alloys, PhD thesis, McGill University, Montréal, Canada, 2012 
11. Zheng N, Wang HY, Gu ZH, Wang W, Jiang QC. Development of an effective modifier for hypereutectic $\mathrm{Mg}-\mathrm{Si}$ alloys. J Alloys Compd. 2008;463:L1-L4.

12. Mirshahi F, Meratian M. High temperature tensile properties of modified $\mathrm{Mg} / \mathrm{Mg}_{2} \mathrm{Si}$ in situ composite. Mater Des. 2012;33:557-62.

13. Huang Y, Dieringa H, Kainer KU, Hort N. Understanding effects of microstructural inhomogeneity on creep responsenew approaches to improve the creep resistance in magnesium alloys. J Magnes Alloy. 2014;2:124-32.

14. Mendis CL, Bettles CJ, Gibson MA, Gorsse S, Hutchinson CR. Refinement of precipitate distributions in an age-hardenable $\mathrm{Mg}-$ Sn alloy through microalloying. Philos Mag Lett. 2006;86:443-56.

15. Rzychoń T, Dybowski B. The influence of aluminum on the microstructure and hardness of $\mathrm{Mg}-5 \mathrm{Si}-7 \mathrm{Sn}$ alloy. Arch Metall Mater. 2016;61:425-32.

16. Lu YZ, Wang QD, Zeng XQ, Zhu YP, Ding WJ. Behavior of Mg$6 \mathrm{Al}-\mathrm{xSi}$ alloys during solution heat treatment at $420^{\circ} \mathrm{C}$. Mater Sci Eng A. 2001;301:255-8.

17. Kim YK, Do Kim H, Kim WT, Kim DH. Precipitation of $\mathrm{DO}_{19}$ type metastable phase in Mg-Sn alloy. Mater Lett. 2013;113:50-3.

18. Mendis CL, Bettles CJ, Gibson MA, Hutchinson CR. An enhanced age hardening response in $\mathrm{Mg}-\mathrm{Sn}$ based alloys containing $\mathrm{Zn}$. Mater Sci Eng A. 2006;435-436:163-71.

19. Zhang M, Zhang W-Z, Zhu GZ. The morphology and crystallography of polygonal $\mathrm{Mg}_{2} \mathrm{Sn}$ precipitates in a $\mathrm{Mg}-\mathrm{Sn}-\mathrm{Mn}-\mathrm{Si}$ alloy. Scr Mater. 2008;59:866-9.

20. Huang X, Zhang W, Ma Y, Yin M. Enhancement of hardening and thermal resistance of $\mathrm{Mg}-\mathrm{Sn}$-based alloys by addition of $\mathrm{Cu}$ and Al. Philos Mag Lett. 2014;94:460-9.

21. Sasaki TT, Elsayed FR, Nakata T, Ohkubo T, Kamado S, Hono K. Strong and ductile heat-treatable $\mathrm{Mg}-\mathrm{Sn}-\mathrm{Zn}-\mathrm{Al}$ wrought alloys. Acta Mater. 2015;99:176-86.

22. Zhang M, Zhang W, Zhu G, Yu K. Crystallography of $\mathrm{Mg}_{2} \mathrm{Sn}$ precipitates in $\mathrm{Mg}$-Sn-Mn-Si alloy. Trans Nonferrous Met Soc China. 2007; 17:1428-32.

23. Elsayed FR, Sasaki TT, Mendis CL, Ohkubo T, Hono K. Compositional optimization of $\mathrm{Mg}-\mathrm{Sn}-\mathrm{Al}$ alloys for higher age hardening response. Mater Sci Eng A. 2013;566:22-9.

24. Behdad S, Zhou L, Henderson HB, Manuel MV, Sohn Y, Agarwal A, Boesl B. Improvement of aging kinetics and precipitate size refinement in $\mathrm{Mg}-\mathrm{Sn}$ alloys by hafnium additions. Mater Sci Eng A. $2016 ; 651: 854-8$

25. Humaun Kabir A, Su J, Sanjari M, Jung I-H, Yue S. Agehardening response of Mg-Al-Sn Alloys. Mater Sci Forum. 2015;828-829:250-5.

26. Son $\mathrm{H}$, Lee J, Jeong $\mathrm{H}$, Konno TJ. Effects of $\mathrm{Al}$ and $\mathrm{Zn}$ additions on mechanical properties and precipitation behaviors of $\mathrm{Mg}-\mathrm{Sn}$ alloy system. Mater Lett. 2011;65:1966-9.

27. Caceres CH, Rovera DM. Solid solution strengthening in concentrated Mg-Al alloys. J Light Met. 2001;1:151-6.

28. Dieter GE, Bacon DJ. Mechanical metallurgy, vol. 3. New York: McGraw-hill; 1986.

29. Kassner ME, Pérez-Prado MT. Fundamentals of creep in metals and alloys. New York: Elsevier; 2004.

30. Watanabe H, Tsutsui H, Mukai T, Kohzu M, Tanabe S, Higashi $\mathrm{K}$. Deformation mechanism in a coarse-grained $\mathrm{Mg}-\mathrm{Al}-\mathrm{Zn}$ alloy at elevated temperatures. Int J Plast. 2001;17(3):387-97.

31. Watanabe H, Tsutsui H, Mukai T, Kohzu M, Tanabe S, Higashi $\mathrm{K}$. Effect of temperature and grain size on the dominant diffusion process for superplastic flow in an AZ61 magnesium alloy. Acta Mater. 1999;47(14):3753-8.

32. Somekawa H, Hirai K, Watanabe H, Takigawa Y, Higashi K. Dislocation creep behavior in $\mathrm{Mg}-\mathrm{Al}-\mathrm{Zn}$ alloys. Mater Sci Eng A. 2005;407(1-2):53-61.

33. Athul KR, Pillai UTS, Srinivasan A, Pai BC. A review of different creep mechanisms in $\mathrm{Mg}$ alloys based on stress exponent and activation energy. Adv Eng Mater. 2016;18(5):770-94.

34. Chelliah NM, Kraemer L, Singh H, Surappa MK, Raj R. Stress-rupture measurements of cast magnesium strengthened by in-situ production of ceramic particles. J Magnes Alloy. 2017;5(2):225-30.

35. Kanga YH, Wang XX, Zhang N, Yana H, Chen RS. Effect of initial temper on the creep behavior of precipitation-hardened WE43 alloy. Mater Sci Eng A. 2017;689:419-26.

Publisher's Note Springer Nature remains neutral with regard to jurisdictional claims in published maps and institutional affiliations. 